\title{
Model Pembelajaran Berbasis Game Flash Tau Jo Huruf bagi Anak Downsyndrome
}

\begin{tabular}{|c|c|}
\hline & $\begin{array}{l}\text { nin } \text { safrial }^{1}, \text { Marlina }^{2}, \text { Irdamurni }^{3} \\
\text { Email: ridwanbinsafrial12345@gmail.com }\end{array}$ \\
\hline INFORMASI ARTIKEL & ABSTRAK \\
\hline $\begin{array}{l}\text { terkirim } 25 \text { Januari } 2018 \\
\text { Revisi } 27 \text { January } 18 \\
\text { Diterima } 29 \text { February } 18\end{array}$ & $\begin{array}{l}\text { Anak down syndrome masih bisa meningkatkan kemampuan mereka dalam } \\
\text { mengenal huruf walau dibayangi keterbatasan intelegensi, maka } \\
\text { diciptkanlah sebuah model pembelajaran mengenal huruf berbsasis game }\end{array}$ \\
\hline $\begin{array}{l}\text { Kata kunci: } \\
\text { Model pembelajaran } \\
\text { mengenal huruf, } \\
\text { Downsydrome, Game Tau } \\
\text { Jo Huruf }\end{array}$ & $\begin{array}{l}\text { flash game ini diberi nama Tau Jo Huruf, Jenis penelitian adalah penelitian } \\
\text { pengembangan ( R \& D ), yang mengacu pada teori Borg and Gall (1983). } \\
\text { Subjek penelitian adalah siswa downsyndrome SMPLB dan SMALB di } \\
\text { YPPLB Padang. Penelitian menghasilkan suatu model pembelajaran } \\
\text { mengenal huruf berbasis game yang dijalankan pada perangkat komputer } \\
\text { untuk mengenalkan pada anak downsyndrome. }\end{array}$ \\
\hline
\end{tabular}

\section{Pendahuluan}

Ditemukan sebuah potensi pada diri anak downsyndrome yang duduk di kelas SMPLB dan SMALB YPPLB Padang, mereka mampu menggunakan teknologi smartphone. Perangkat telekomunikasi serbaguna ini mampu memikat anak downsyndrome terutama dari segi aspek bermain game. Sebagian besar dari mereka mampu memahami perintah dan notifikasi yang yang muncul pada sebuah game, mereka juga memahami apa saja yang bisa diakses dalam sistem sebuah game yang tergambarkan melalui user interface-nya. Oleh karena itu perangkat lunak komputer khususnya game menjadi layak untuk dikembangkan sebagai sebuah model pembelajaran mengenal huruf bagi anak downsyndrome.

Berdasarkan penelitian yang dilakukan oleh Joyce dan Weil (1996) dan Joyce, Weil, dan Shower (1992), setiap pendekatan yang ditelitinya dinamakan model pembelajaran, meskipun salah satu dari beberapa istilah lain digunakan seperti strategi pembelajaran, metode pembelajaran, atau prinsip pembelajaran. Tujuan dari penelitian pengembangan ini adalah untuk menciptakan Model Pembelajaran Mengenal Huruf Berbasis Game Flash Tau Jo Huruf Bagi Anak Down Syndrome, sesuai dengan rumusan masalah yang telah dipaparkan sebelumnya maka tujuan dari pengembangan ini adalah (1) Untuk mengetahui kegunaan model pembelajaran mengenal huruf berbasis game flash tau jo huruf bagi anak down syndrome (2) Untuk mengetahui tingkat kelayakan model pembelajaran mengenal huruf berbasis game flash tau jo huruf bagi anak down syndrome (3) Untuk mengetahui keunggulan model pembelajaran mengenal huruf berbasis game flash tau jo huruf bagi anak down syndrome.

Spesifikasi mejelaskan semua identitas penting yang dapat digunakan untuk membedakan antara produk satu dengan produk yang lain, maka spesifikasi produk yang akan dikembangkan dalam penelitian ini adalah (1) Model pembelajaran mengenal huruf berbasis game flash tau jo huruf bagi anak down syndrome mengedepankan kegiatan belajar mandiri bagi anak down syndrome (2) Materi dari Model pembelajaran mengenal huruf berbasis game flash tau jo huruf bagi anak down syndrome meliputi mengenalkan anak dengan huruf alphabet a sampai z (3) Model pembelajaran mengenal huruf berbasis game flash tau jo huruf bagi anak down syndrome sepenuhnya berbentuk media operasional software atau perangkat lunak computer (4) Media ini memanfaatkan perangkat keras komputer dan tidak menuntut kemampuan khusus, hanya membutuhkan kemampuan sederhana dalam pengoperasian mouse meliputi click, drag and drop dan double click (5) Aplikasi ini dikembangkan dengan software Adobe Photoshop CC 2017 digunakan untuk design user interface, Adobe Animate CC 2017 digunakan untuk memprogram dan mengatur UI (user interface) dari game, Adobe Ilustrator CC 2017 digunakan untuk mendesain vector graphic dari komponen-komponen UI, Adobe Audition CC 2017 digunakan untuk voice recorder sebagai backsound vokal huruf saat bermain, Icon Workshop untuk mengekstrak image yang akan dijadikan Icon tampilan dari aplikasi, dan Mproject sebagai media untuk convert aplikasi berekstensi flash ke format .exe. 


\section{Metode}

Metode yang digunakan dalam penelitian yaitu jenis pendekatan metode penelitian dan pengembangan (Research and Development). Penulisan dan pengembangan pendidikan meliputi beberapa tahapan dimana di dalamnya suatu model dikembangkan, diteskan, dan direvisi sesuai hasil tes lapangan. Tahapan proses penulisan pengembangan model pembelajaran mengenal huruf berbasis game tau jo huruf bagi anak down syndrome dilakukan secara bertahap, yang mana pada setiap langkah yang dikembangkan selalu mengacu pada hasil langkah-langkah sebelumnya dan pada akhimya di peroleh suatu model pendidikan yang baru.

Melalui penelitian dan pengembangan, peneliti berusaha untuk mengembangkan produk berupa modep pembelajaran mnegenal huruf yang layak dan efektif digunakan dalam pendidikan anak down syndrom. Menurut Richey and Kelin dalam Sugiyono (2015:28-29) bidang pembelajaran menyatakan bahwa penelitian ini sekarang dinamakan Design And Development Research. Sebelumnya dinamakan Development Research. Design And Development adalah, "the systematic study of design, development and evaluation processes with the aim of establishing an empirical basis for the creation of instructional and noninstructional produk and tool and new or enhanced model that govern their development". Perancangan dan penelitian pengembangan adalah kajian yang sistematis tentang bagaimana membuat rancangan suatu produk, mengembangkan/ memproduksi rancangan tersebut, dengan tujuan dapat diperoleh data yang empiris yang dapat digunakan dalam pembelajaran atau non pembelajaran.

Dalam hal pendidikan, Borg and Gall dalam Sugiyono (2015-34) mendefenisikan R \& D sebagai berikut. "Educational Research Design And Development (Educational $R \& D$ ) is an industry-based development model in which the findings of the research are used to design new products and procedures, which then are sysstematically field-tested, evaluated, and refined until they meet specified criteria of effectiveness, quality, or similiar standard". Penelitian dan pengembangan dalam pendidikan didasarkan pada model penelitian dan pengembangan pada industri, dimana hasil penelitian digunakan untuk merancang produk baru dan prosedur, dan selanjutnya diuji lapangan secara sistematis, dievaluasi dan disempurnakan sampai memenuhi kriteria yang spesifik yaitu efektivitas, kualitas, dan memenuhi standart.

\section{Hasil}

\section{A. Hasil Data Uji Validasi Ahli}

Berikut adalah hasil dari proses pengembangan model yaitu uji validasi yang dilakukan oleh Ahli dibidang Teknologi Pendidikan Dr. Ulfia Rahmi, S.Pd, M.Pd, ahli dibidang Bahasa Dra. Hj. Zulmiyetri, M.Pd dan ahli dibidang pendidikan anak berkebutuhan khusus Drs. Ardisal, M.Pd.

Tabel 1. uji coba materi

\begin{tabular}{|c|c|c|}
\hline \multirow[t]{2}{*}{ No } & \multirow[t]{2}{*}{ Aspek } & Penilaian \\
\hline & & Validator \\
\hline 1 & Bermain degan huruf A sampai Z & 4 \\
\hline 2 & Mengenal huruf A sampai Z & 4 \\
\hline 3 & $\begin{array}{l}\text { Mendiskriminasikan Huruf A } \\
\text { samapai Z }\end{array}$ & 1 \\
\hline 4 & Mengingat huruf A sampai Z & 1 \\
\hline & JUMLAH & 10 \\
\hline & RATA RATA & 2.25 \\
\hline
\end{tabular}


Tabel 2. Uji coba media game

\begin{tabular}{llc}
\hline No & \multicolumn{1}{c}{ Aspek } & $\begin{array}{c}\text { Penilaian } \\
\text { Validator }\end{array}$ \\
\hline 1 & $\begin{array}{l}\text { Menyediakan program belajar } \\
\text { sambil bermain }\end{array}$ & 4 \\
2 & $\begin{array}{l}\text { Melibatkan peserta didik dalam } \\
\text { memanfaatkan media }\end{array}$ & 4 \\
3 & Menghasilkan pesan menarik & 4 \\
4 & Mempunyai tombol yang dapat & 4 \\
5 & mengatur tinggi rendahnya suara & 4 \\
6 & Ada reward bagi pemain & 4 \\
7 & Ada hukuman jika gagal & 3 \\
& $\begin{array}{l}\text { Ukuran dari huruf yang } \\
\text { digunakan cukup jelas }\end{array}$ & 4 \\
& Huruf mudah dimengerti & 31 \\
& $\quad$ JUMLAH & 3.8 \\
\hline
\end{tabular}

Tabel 3. uji coba bahasa game

\begin{tabular}{llc}
\hline No & \multicolumn{1}{c}{ Aspek } & $\begin{array}{c}\text { Penilaian } \\
\text { Validator }\end{array}$ \\
\hline 1 & & 4 \\
2 & Bahasa yang digunakan game & 4 \\
3 & cukup jelas & 4 \\
& Bahasa game mudah dimengerti & 12 \\
& Penempatan bunyi huruf & 4 \\
& \multicolumn{1}{c}{ JUMLAH } & \\
\hline
\end{tabular}

Tabel 4. uji coba bermain

\begin{tabular}{|c|c|c|}
\hline \multirow[t]{2}{*}{ No } & \multirow[t]{2}{*}{ Aspek } & \multirow{2}{*}{$\begin{array}{l}\text { Penilaian } \\
\text { Validator }\end{array}$} \\
\hline & & \\
\hline 1 & $\begin{array}{l}\text { Menyediakan ruang bahasa yang } \\
\text { benar }\end{array}$ & 4 \\
\hline 2 & $\begin{array}{l}\text { Game mempunyai petunjuk awal } \\
\text { bermain }\end{array}$ & 1 \\
\hline 3 & $\begin{array}{l}\text { Game memberikan tantangan } \\
\text { berupa jika mouse terlepas pada } \\
\text { kotak yang tidak benar maka } \\
\text { huruf akan kembali pada posisi } \\
\text { awal }\end{array}$ & 4 \\
\hline 4 & $\begin{array}{l}\text { Game menyediakan tantangan } \\
\text { jika mouse terlepas pada area } \\
\text { kosong maka huruf akan kembali } \\
\text { pada posisi awal }\end{array}$ & 4 \\
\hline & JUMLAH & 13 \\
\hline & RATA RATA & 3.2 \\
\hline
\end{tabular}




\section{Diskusi}

\section{A. Analisis Hasil Uji Validasi}

Penyelesaian penelitian pengembangan dilakukan berdasarkan tahapan prosedur penelitian pengembangan yang diadaptasi dari prosedur pengembangan Borg and Gall, yaitu masalah dan potensi, pengumpulan data, desain produk, validasi desain, revisi desain, uji coba pemakaian dan hasil akhir. Maka, analisis data penelitian pengembangan menggunakan analisis data kuantitatif.

Tahap awal penelitian pengembangan peneliti mengembangkan desain model dan peneliti meminta kepada tiga validator ahli Teknologi Pendidikan, ahli bahasa dan ahli Penididikan Luar Biasa untuk memberikan penilaian dan saran untuk kualitas produk. Kemudian peneliti merevisi model sesuai dengan saran yang diberikan oleh ketiga validator, peneliti mengalami beberapa hambatan pada tahap pengembangan produk. Pertama, pembuatan produk ini memerlukan waktu yang cukup lama dikarenakan butuhnya keahlian khusus dalam pembuatan produk tersebut. Selain itu, dalam pengembangan model peneliti mengerjakan tidak menggunakan tim khusus, sehingga waktu memang menjadi masalah utama dalam proses ini.

Seperti pada saat pengembangan model, setelah uji validasi oleh ahli terkait maka model perlu direvisi ulang sesuai saran dari ketiga validator ahli bidang Pendidiakan Luar Biasa, Bahasa dan teknologi pendidikan. Hasilnya model mengalami perubahan besar besaran disamping strategi bermain dalam model yang tetap dipertahankan. Perubahan itu meliputi, pengisi suara dari setiap huruf, soundtrack, warna tampilan, tampilan pembuka, pemberian kotak hadiah pada setiap stage yang diselesaikan dan penambahan jumlah stage.

Selanjutnya penilaian dari tiga validator ahli dari uji validasi pengembangan produk dikonversikan kedalam nilai kualitatif (A-E). Sehingga diketahuai produk berdasarkan penilaian ahli validator, hasil analisis data dari validasi ahli diuraikan sebagai berikut:

Tabel. 5 Analisis Hasil Validasi Ahli

\begin{tabular}{cccccc}
\hline No & Aspek & $\begin{array}{c}\text { Jumlah skor } \\
\text { penilaian }\end{array}$ & $\begin{array}{c}\text { Rata- rata } \\
\text { skor }\end{array}$ & $\begin{array}{c}\text { Nilai } \\
\text { kualitatif }\end{array}$ & Kategori \\
\hline & Materi & 10 & 2.25 & C & Kurang \\
1 & 12 & 4 & A & Saik \\
2 & Bahasa & 13.5 & 3.35 & B & Baik \\
3 & Bermain & 28 & 3.45 & B & Baik \\
4 & Game & & & & Baik \\
\hline
\end{tabular}

Maka, diketahui bahwa hasil yang diperoleh dari aspek penilaian sudah sangat memuaskan namun masih ada kekurangan yang harus diperbaiki, sehingga alat dapat direvisi kembali sesuai dengan harapan.

\section{B. Revisi Model}

Berdasarkan prosedur yang telah diadaptasi dari Borg and Gall setelah analisis data validasi oleh dua validator, peneliti melakukan beberapa revisi. Hasil revisi tersebut dapat dilihat sebagai berikut:

1. Revisi dari validator ahli Teknologi Pendidikan, perbaikan yang disampaikan adalah tampilan reward bagi player dan penambahan materi

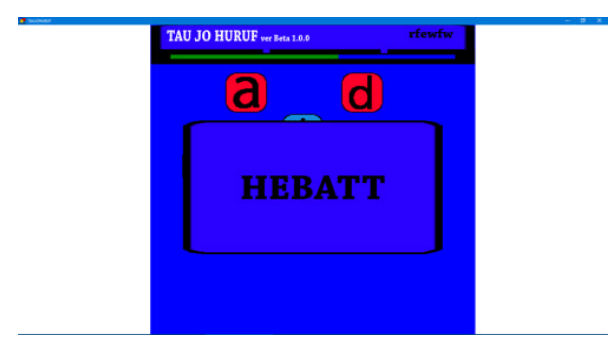

Sebelum revisi

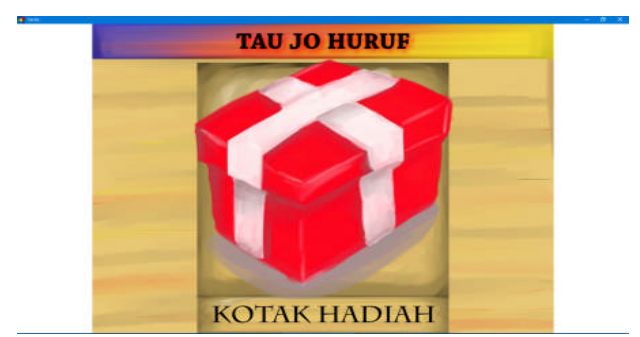

Setelah revisi 
2. Revisi dari validator ahli Pendidikan Anak Berkebutuhan Khusus, perbaikan yang disampaikan adalah Petunjuk bermain dari produk, kejelasan dari kerja produk dalam membimbing anak untuk bermain dengan huruf.

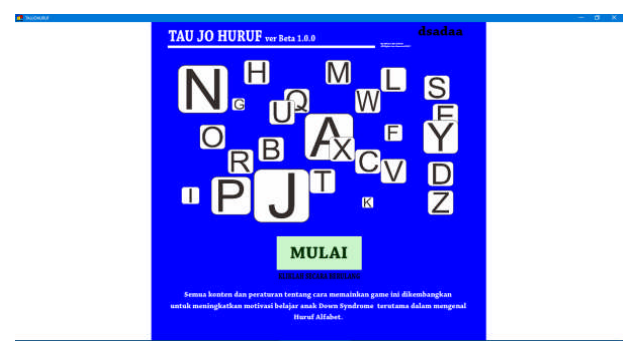

Sebelum revisi

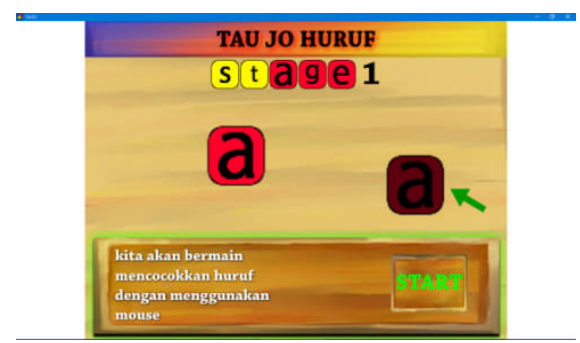

Setelah revisi

3. Revisi dari ahli bahasa perbaikan disampaikan dari sisi materi, adalah misi mengenalkan huruf dilanjutkan sampai pada tahap diskriminasi dan mengingat huruf, agar konsep mengenal huruf semakin lebih matang lagi.
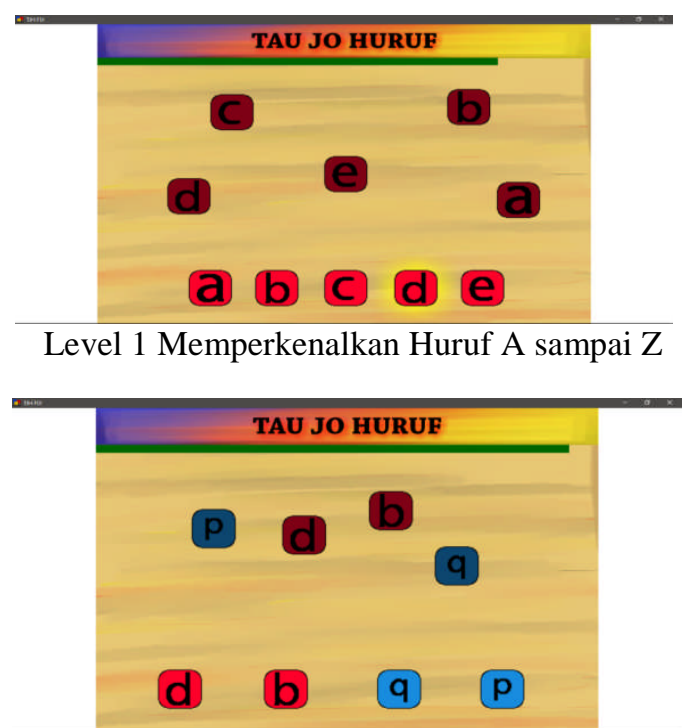

Level 2 Mendiskriminasikan Huruf A sampai Z

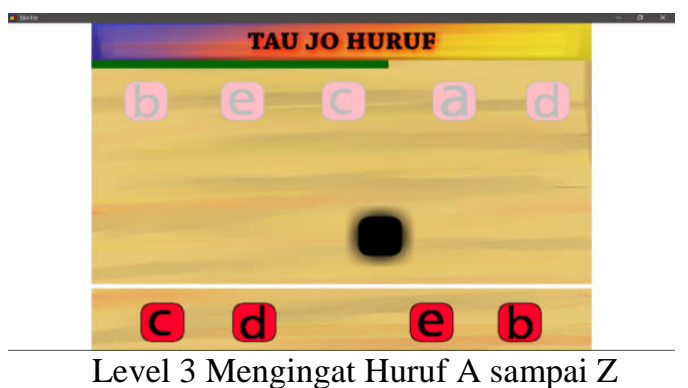

\section{Kesimpulan}

Model pembelajaran mengenal huruf berbasis game flash tau jo huruf bagi anak down syndrome berguna sebagai model pembelajaran yang memperkenalkan huruf alphabet a sampai z. Valiadator dari model pembelajaran berbasis game tau jo huruf telah memberikan skor yang baik sehingga produk sudah ditetapkan menjadi wahana belajar yang tepat bagi anak down syndrome. 
Perbaikan spesifikasi awal dari model pembelajaran mengenal huruf berbasis game flash tau jo dilakukan atas penilaian yang dilakukan oleh para ahli baik itu dari sisi teknologi game, dan materi mengenal huruf bagi anak down syndrome, sehingga kelayakan dari model ini sudah teruji secara terbatas.

Model pembelajaran ini memanfaatkan perangkat lunak komputer sebagai pembelajaran mengenal huruf bagi anak down syndrome. Game ini memperkenalkan anak dengan huruf alphabet a sampai z dengan cara kerja yang ada dalam sebuah game, sehingga anak dapat lebih tertarik untuk mengenal huruf. Disamping itu game ini dkembangkan dan dibangun dengan perangkat lunak yang uptodate sehingga bug dan kesalahan visual hampir tidak terlihat sama sekali.

\section{Daftar Rujukan}

Ahmad Akrom Nur Fuqoha. 2015. Penngembangan Game RPG Sebagai Media Pembelajaran Berbasis Guided Inquiry Pada Materi Segiempat dan Segitiga Untuk Anak SMP Kelas VII. Yogyakarta: eprint.uny.ac.id.

Anonim. 2013. Membuat Game Interaktif Menggunakan Adobe Flash CS6: Hidden Objek, scary maze, puzzle, tangkap objek, fighter plane, beda gambar, snake brake, dan avoiding. Yogyakarta. ANDI dan Wahana Komputer.

Gunarhadi. 2005. Penanganan Anak Sindroma Down dalam Lingkungan Keluarga dan Sekolah. Jakarta: Departemen Pendidikan Nasional Direktorat Jenderal Pendidikan Tinggi Direktorat Direktorat Pembinaan Pendidikan Tenaga Kependidikan dan Ketenagaan Perguruan Tinggi.

Ghea Putri Fatma Dewi. 2012. Pengembangan Game Edukasi Pengenalan Nama Hewan Dalam Bahasa Inggris Sebagai Media Pembelajaran Anak SD Berbasis Macromedia Flash. Yogyakarta: eprint.uny.ac.id.

Henry, Samuel. 2010. Cerdas dengan Game: Panduan Praktis Bagi Orang Tua dalam Mendampingi Anak Bermain Game. Jakarta: KOMPAS GRAMEDIA.

Keraf, Gorys. 1994. Komposisi. Jakarta: Nusa Indah.

Martini, Jamaris. 2009. Kesulitan Belajar. Jakarta: Yayasan Penamas Murni.

Perkins, Tom. 2014. ActionScript 3.0 In Flash Professional CS5 Essential Training. www.Adobe.com

Radion, Kristo. 2009. Ultimate Game Design: Building RPG Games Using Adobe Flash ActionScript. Yogyakarta: ANDI.

Sunyoto, Andi. 2010. Adobe Flash + XML = Rich Application: Sebuah Integrasi Antara Aplikasi Multimedia dan Database dalam Mengahasilkan Rich Multimedia Application. Yogyakarta: ANDI.

Sugiyono. 2015. Metode Penelitian \& Pengembangan Research and Development. Bandung: ALFABETA.

Tim Litbang Wahana Komputer. 2014. Mudah Membuat Game Android Bebasis Adobe AIR. Yogyakarta. ANDI dan Wahana Komputer. 